Relations industrielles

Industrial Relations

\title{
La Confiance au travail, Coordonné par Laurent Karsenty, Toulouse : Octarès éditions, 2013, 213 pages. ISBN : \\ 978-2-36630-019-2.
}

\section{Sylvain Luc}

Volume 69, numéro 1, hiver 2014

URI : https://id.erudit.org/iderudit/1024215ar

DOI : https://doi.org/10.7202/1024215ar

Aller au sommaire du numéro

\section{Éditeur(s)}

Département des relations industrielles de l’Université Laval

\section{ISSN}

0034-379X (imprimé)

1703-8138 (numérique)

Découvrir la revue

Citer ce compte rendu

Luc, S. (2014). Compte rendu de [La Confiance au travail, Coordonné par Laurent Karsenty, Toulouse : Octarès éditions, 2013, 213 pages. ISBN :

978-2-36630-019-2.] Relations industrielles / Industrial Relations, 69(1), 222-224.

https://doi.org/10.7202/1024215ar

Tous droits réservés @ Département des relations industrielles de l’Université Laval, 2014
Ce document est protégé par la loi sur le droit d'auteur. L’utilisation des services d'Érudit (y compris la reproduction) est assujettie à sa politique d'utilisation que vous pouvez consulter en ligne.

https://apropos.erudit.org/fr/usagers/politique-dutilisation/ 
expanded upon Smith's theories. In the last section of the book the author relates the material to economic development, drawing on a number of studies which show how the division of labour and the involvement of the market shaped the industrial revolution. The contribution of the division of labour to modern theories of the firm is discussed and Sun concludes by noting that there is still much to learn about how economies create and diffuse wealth. In these very challenging global economic times this is a very appropriate place to finish; although readers might want to know a little more about how economics can contribute to some new thinking about a way forward.

\section{Robyn May}

Griffith University, Brisbane Australia

\section{La Confiance au travail}

Coordonné par Laurent Karsenty, Toulouse : Octarès éditions, 2013, 213 pages. ISBN : 978-2-36630-019-2.

C'est un fait avéré : la confiance constitue une condition nécessaire à la mobilisation et à l'engagement organisationnels. Les enjeux de sécurité, de prévention, de qualité de vie au travail, de performance, d'adaptation et de résilience organisationnelles dépendent directement de son existence et de sa subsistance. Pourtant, malgré cette évidence, il apparaît, au vu de récentes enquêtes dont la presse économique se fait souvent l'écho, que la confiance au travail s'érode inexorablement depuis plusieurs années. Comme le souligne d'entrée de jeu Corrine Chabaud en préfaçant l'ouvrage, cette condition de l'action et de la coopération n'a jusqu'ici pas bénéficié, en milieu francophone, d'un traitement de fond analytique. Nous ne pouvons donc que saluer cette heureuse initiative qui vient combler ce manque et qui, nous le souhaitons, incitera à de futures contributions.

Le présent ouvrage combine huit contributions de professeurs et chercheurs universitaires ainsi que d'intervenants en milieu de travail. Les différents auteurs, au départ de leur discipline (psychologie, ergonomie, sociologie des organisations, sciences de gestion) et de leur pratique professionnelle (recherche en sciences humaines, intervention, conseil en organisation et GRH), ont construit leurs réflexions en tentant de répondre aux trois questions suivantes:

- Comment définir et penser la confiance au travail ?

- Comment comprendre son importance ?

- Comment agir pour favoriser son développement et son maintien, voire pour la restaurer? (p. 3)

L'ouvrage est divisé en deux parties de quatre contributions chacune. La première partie propose des cadres conceptuels et interprétatifs visant à appréhender le travail sous le prisme de la confiance. Nous retiendrons particulièrement la contribution de Laurent Karsenty qui, à l'instar de Niklas Luhmann, nous invite à penser la confiance comme un moyen de réduction de l'incertitude inhérente aux relations de travail. Partant, l'acteur organisationnel est à la recherche de "ressources de confiance » au sein de son organisation qui lui permettraient de faire face aux risques qui pèsent sur son travail (risques sur le sens ou sur la réussite du travail), et ce, selon les situations qu'il serait amené à rencontrer. Les compétences, la fiabilité, la franchise et l'honnêteté, le souci de l'autre et I'identification à l'autre sont autant de caractéristiques qui seront prises en compte dans cette sélection. Conscient du caractère systémique de ce processus (la confiance structure la relation tout autant que cette dernière la construit) et dans le but d'explorer ses évolutions (du renforcement à la dégradation), l'auteur propose un modèle intégrateur de cette production dynamique de la confiance au sein de l'organisation. L'une des valeurs ajoutées de ce modèle réside dans la prise en considération de l'influence implicite du contexte culturel et organisationnel sur ce processus dynamique. Si la confiance se construit au départ 
d'attentes explicitées, elle est aussi déterminée par des attentes implicites et tacites qui se fondent sur des valeurs partagées, parfois inconsciemment, au sein de l'organisation.

Pointons également le regard d'inspiration maussienne développé par Jérôme Koch (chapitre 3), pour qui un climat de confiance ne peut se développer au sein de l'organisation que si les échanges entre les acteurs se structurent autour d'un cycle de dons (donner, recevoir, rendre). Or, ce cycle dépend lui-même des modes de régulation en entreprises (fixation d'objectifs, définitions d'indicateurs, de procédures, modes d'évaluation) qui sont souvent bien éloignés du réel du travail. L'auteur vient donc réaffirmer l'intérêt d'une approche conjointe et collaborative de la définition de ces cadres de régulation au sein de l'entreprise, et ce, afin de tenir compte de la réalité du travail et des échanges de coopération au sein de l'entreprise.

Enfin, toujours dans cette première partie, soulignons également l'étude de cas réalisée par Adeline Pernet et Vanina Mollo dans le domaine des soins de santé (radiothérapie). Les auteures nous rappellent que, bien au-delà d'être une relation de soin, le rapport entre personnels soignants et patients apparaît avant tout comme une relation humaine basée sur la confiance. Non seulement, le souci du patient (le care) est un déterminant essentiel à la construction de cette confiance, mais aussi il vient soutenir la coproduction d'un soin sûr et efficace. Partant, le patient en confiance devient lui-même acteur de sa cure. Bien que restreinte au cas particulier du cadre hospitalier, l'étude nous invite à percevoir les avantages en termes d'efficacité que procure le développement d'une relation de confiance avec les bénéficiaires, mais aussi plus largement, avec l'ensemble des parties prenantes de l'organisation.

La seconde partie de l'ouvrage, à finalité plus pragmatique, présente des pistes d'action visant à favoriser le développement de la confiance au travail. Elle s'ouvre avec une réflexion de Michel Perron sur l'importance du tiers facilitateur dans la résolution de conflits ou de situation où la confiance entre acteurs sociaux s'est détériorée. Si l'intervenant externe agit sur le conflit en arbitrant parfois le contenu des échanges entre les acteurs, c'est surtout en sécurisant le cadre de ces échanges, en ouvrant un espace d'écoute mutuelle, qu'il permet la restauration progressive de la confiance. Retenons également la contribution ambitieuse de Didier Bonnin (chapitre 7) qui, au départ d'une analyse critique des méthodes de management basé sur les résultats (MBR) et de management basé sur les moyens (MBM), et de leurs impacts négatifs sur la confiance, propose les fondements d'un nouveau modèle de management basé sur le travail (MBW), faisant de ce dernier la ressource essentielle et centrale de la structuration de l'organisation. L'ampleur de la tâche est évidemment énorme puisqu'elle implique un changement majeur de paradigme (le management ne se définissant plus en fonction des exigences de l'actionnariat, mais en fonction des exigences du travail). L'auteur en appelle d'ailleurs à de futures collaborations en vue de dépasser ces premières balises et de poursuivre ce chemin de la réhabilitation du sens de l'action.

Globalement, pour user d'une métaphore musicale, à défaut d'être un opéra, ce livre constitue une belle " ouverture ». II met en scène plusieurs thèmes cruciaux qui, nous l'espérons, feront l'objet de développements et d'approfondissements futurs. Nous noterons toutefois un petit bémol. Les contributeurs semblent envisager la confiance exclusivement comme un contrat rationnel, calculé, décidé entre différents protagonistes structurant les conditions d'un échange qui se doit d'être équilibré. En ce sens, les auteurs perçoivent la confiance comme une sorte de compromis plus ou moins négocié mettant chacun sur le même plan, supprimant les risques individuels, homogénéisant la relation, gommant les enjeux symboliques sous-jacents à toute relation. Cependant, à y regarder de plus près, ce contrat, 
par ses clauses implicites de renonciation, définit tout autant la confiance que la méfiance. Partant, développer la confiance pourrait se limiter à diminuer la méfiance. Selon nous, il s'agit là d'une vision un peu réductrice de la confiance qui pourrait évacuer le réel de l'humain au travail. En effet, il existe aussi une confiance de l'ordre du spontané, du non rationalisé sans pour autant être aveugle. Une confiance qui implique un "laisser advenir " tout autant qu'elle le permet. Cette dernière soulève le besoin de prendre un risque de s'abandonner à l'autre, un risque nécessairement sans garantie. Si la confiance peut être considérée comme un moyen visant à réduire l'incertitude en homogénéisant la relation de travail, il ne faudrait pas occulter le fait qu'elle est aussi source d'un risque, symbolique cette fois, inscrit dans l'altérité et la différence.

\section{Sylvain Luc}

Université Laval

\section{The State of Working America}

By Lawrence Mishel, Josh Bivens, Elise Gould and Heidi Shierholz, Ithaca, New York: ILR Press, Cornell University, 2012 (12 ${ }^{\text {th }}$ edition), 505 pages. ISBN: 978-0801478550.

The State of Working America by Mishel, Bivens, Gould (no relation to me), and Shierholz, put out by the Economic Policy Institute, is now in its 12th edition. There is a rumor doing the rounds that this may be its last version; disturbing news in my humble opinion. I reviewed the 11 th edition of this book for edition 66 (2) of Relations industrielles/Industrial Relations, published in 2011. This earlier tome dealt with the period ending just before 2008's financial crisis. In my previous appraisal for the series, I said positive things about the work. In fact, I gave it a glowing endorsement. I can now report without exaggeration that, for several years, there would have been very few weeks when I did not flip through its pages to check on a point, and/or add nuance, and/or substance to something I was thinking. Without being immodest, I consider that I am becoming an expert on this series; and, in the process, sinking into deeper depression.

Anyway, the 12th edition is every bit as good as its predecessor -probably a little better; and that is saying something. Drawing on diverse sources, the series presents tabulated and graphic data about the American labor market and, in its narrative, gives a first-blush reading of such data. It then goes further, and -in so doingbecomes profound. It addresses the issue of interpretation. The main difference between the latest version of the work and its earlier incantations is that the new edition references the 2008 global financial crisis, the so-called "Great Recession", to create context for the subject matter. This was perhaps inevitable given that, in a technical sense, each edition of the book can be characterized as using panel data to create a longitudinal/historical perspective of what is happening to the American workforce; and American society.

This series is wonderful. However, be warned. To get the most out of it you have to put asunder preconceptions, particularly if you are American and/or watch Fox news. I was thinking about how to express this latter thought and here is what I have come up with: you will get the most out of the book if you start reading it as an ideological virgin.

The thesis of the book -and of the series- is that the American economy, and society, is polarizing in the cruelest and ugliest of ways. This trend started well before the 2008 global financial crisis and has moved into overdrive in the period since. The interesting thing about this phenomenon -and the way it is dealt with in the book- is that, in spite of what I said about the authors' deft touch with interpretation of data, the numbers alone tell most of the story. Hence, if one where to examine only the work's many many 